\title{
Persepsi dan Sikap Mahasiswa Terhadap Pendidikan Karakter di Prodi Pendidikan IPS UNY
}

\author{
SALIMAN, ANIK WIDIASTUTI DAN TAAT WULANDARI \\ Jurusan Studi Pendidikan IPSFISUNY \\ e-mail: anin_dyas@yahoo.com
}

\begin{abstract}
Abstrak
Penelitian ini bertujuan mengetahui persepsi dan sikap mahasiswa terhadap pelaksanaan pendidikan karakter di Prodi Pendidikan IPS, FIS, UNY. Jenis penelitian ini adalah Penelitian deskriptif dengan pendekatan kuantitatif. Populasi penelitian adalah mahasiswa Pendidikan IPS angkatan 2008 dan angkatan 2009 yang berjumlah 142 mahasiswa, dan diambil sampel sebesar $50 \%$ yaitu sebanyak 71 mahasiswa dengan teknik proportional random sampling.Hasil penelitian menunjukkan bahwa persepsi mahasiswa Prodi Pendidikan IPS terhadap pelaksanaan pendidikan karakter termasuk dalam kategori baik. Hal ini ditunjukkan dengan 65\% dari responden memiliki persepsi baik. Sikap mahasiswa Prodi Pendidikan IPS terhadap pelaksanaan pendidikan karakter termasuk dalam kategori cukup baik. Hal ini ditunjukkan dengan $67.60 \%$ dari responden memiliki sikap cukup baik.
\end{abstract}

Kata kunci: persepsi, sikap, pendidikan karakter

\begin{abstract}
This research aims to investigate the student's perception and attitude on the implementation of character education in the Study Program of Social Studies Education, Faculty of Social Sciences, Yogyakarta State University. This research is a descriptive research using quantitative approach. The population of this research included 142 social studies students of class 2008 and 2009. 71 students (50\% of the population) were taken as research samples using proportional random sampling technique. The findings show that the perception and the attitude of the social studies students on the implementation of character education is good. This is indicated by $65 \%$ of the respondents who have good perception. Meanwhile, the students' attitudeon the implementation of character education is quite good. This is indicated by $67.60 \%$ of the respondentswho have quite good attitude.
\end{abstract}

Keywords: perception, attitude, character education 


\section{PENDAHULUAN}

Krisis karakter bangsa, inilah masalah serius yang kini sedang kita alami. Berbagai pelanggaran norma dan tindakan tidak etis banyak terjadi di sekeliling kita. Sebagai contoh tindak korupsi telah meraja lela di Indonesia, tindak kriminalitas dan kekerasan mewarnai kehidupan, korupsi, kolusi dan nepotisme marak terjadi.

Berturut-turut kita alami, banyak peristiwa-peristiwa membuat kita khawatir, janganjangan bangsa Indonesia akan mengalami kehancuran dalam waktu dekat ini. Rusaknya moral/karakter bangsa yang ditunjukkan dengan berbagai perilaku-perilaku menyimpang dan lunturnya nilai-nilai budaya timur, seperti sopan santun, jujur, saling menghargai dan menghormati, tanggung jawab, adil, disiplin, kerjasama, kerja keras, dan peduli. Semua nilai-nilai tersebut di atas telah berubah menjadi perilaku yang serba anarkis.

Salah satu cara yang sedang digalakkan untuk memperbaiki karakter bangsa adalah melalui dunia pendidikan. Dunia pendidikan mempunyai peran penting dalam pembentukan generasi penerus bangsa sejak dini. Undang-undang mengamanatkan pemerintah untuk memperhatikan pendidikan karena pendidikan mempunyai kontribusi sangat besar terhadap kemajuan suatu bangsa. Pembangunan di bidang pendidikan akan terus berlangsung demi meningkatkan kualitas sumber daya manusia suatu negara agar mampu bersaing di era global. Salah satu penyebab terjadinya kemerosotan bangsa dalam dunia kerja pada era persaingan global ini adalah ketertinggalan mutu pendidikan. . "... siapa saja yang tidak memenuhi persyaratan kualitas global, akan tersingkir secara alami dengan sendirinya" (Suyanto \& Djihad Hisyam, 2000: 2). Masyarakat harus terus meningkatkan pendidikannya agar dapat terus bersaing dalam era globalisasi.

Pendidikan di semua jenjang pada masa orde baru, lebih mementingkan aspek kognitif dan kurang mengembangkan aspek afektif seperti kecerdasan emosional, selain itu pendidikan juga mengabaikan penanaman nilai-nilai pada siswa (Suyanto \& Djihad Hisyam, 2000: 6). Sistem pendidikan seperti ini menyebabkan kualitas moral masyarakat Indonesia menjadi rendah. Melihat kondisi tersebut maka pendidikan diupayakan untuk meyelipkan nilai-nilai karakter yang diharapkan dimiliki oleh mahasiswa. Salah satu cara yang dilakukan oleh Prodi Pendidikan IPS FIS UNY untuk meningkatkan karakter mahasiswanya ditempuh melalui penyelenggaraan mata kuliah pendidikan karakter.

Mata kuliah pendidikan karakter ini dilaksanakan sesuai dengan amanat pendidikan nasional yang tertuang dalam tujuan pendidikan nasional yang diharapkan tidak hanya mampu membentuk peserta didik yang terampil dan cerdas, melainkan harus mampu membentuk peserta didik yang beriman, bertakwa, berakhlak mulia, mandiri, kreatif agar menjadi warga negara yang baik. Dalam Undang-undang No. 20 tahun 2003 tentang Sistem Pendidikan Nasional dinyatakan bahwa pendidikan berfungsi untuk membangun karakter, watak serta kepribadian bangsa. Oleh sebab itu pendidikan karakter merupakan suatu hal yang sangat penting untuk dilaksanakan di Indonesia. Menurut Wynne dalam Darmiyati Zuchdi (2009: 10), istilah karakter diambil dari bahasa Yunani yang berarti 'to mark" (menandai). Istilah ini lebih difokuskan pada bagaimana upaya pengaplikasikan nilai kebaikan dalam bentuk tindakan atau tingkah laku. Lebih lanjut, Wynne mengatakan ada dua pengertian tentang karakter, yakni pertama, ia menunjukkan bagaimana seseorang bertingkah laku, dan kedua, istilah karakter erat kaitannya dengan personality.

Sebagai aspek kepribadian, karakter merupakan cerminan dari kepribadian secara utuh dari seseorang: mentalitas, sikap dan perilaku. Pendidikan karakter semcam ini lebih tepat sebagai pendidikan budi pekerti. Pembelajaran tentang tata-krama, sopan santun, dan adat istiadat, menjadikan pendidikan karakter semacam lebih menekankan kepada perilaku-perlaku aktual tentang bagaimana seseorang dapat disebut berkepribadian baik atau tidak baik berdasarkan norma-norma yang bersifat kontekstual dan 
kultural.

Pendidikan karakter hendaknya mencakup aspek pembentukan kepribadian yang memuat dimensi nilai-nilai kebajikan universal dan kesadaran kultural di mana norma-norma kehidupan itu tumbuh dan berkembang. Ringkasnya, pendidikan karakter mampu membuat kesadaran transedental individu mampu tewujud dalam perilaku yang konstruktif berdasarkan konteks kehidupan di mana ia berada: memiliki kesadaran global, namun mampu bertindak sesuai konteks lokal.

Pendidikan karakter menurut Febristina Nuraini adalah suatu sistem penanaman nilai-nilai karakter kepada warga sekolah yang meliputi komponen pengetahuan, kesadaran atau kemauan dan tindakan untuk melaksanakan nilai-nilai tersebut baik terhadap Tuhan YME, diri sendiri, sesama, lingkungan maupun kebangsaan sehingga menjadi manusia insan kamil (2012: 86).

Bertolak dari pendapat tersebut dapat disimpulkan bahwa pendidikan karakter tidak hanya berhubungan dengan orang lain, tetapi juga berkaitan dengan perilaku kita terhadap Tuhan YME, diri sendiri, lingkungan dan bangsa. Persoalan baik dan buruk, kebajikankebajikan, dan keutamaan-keutamaan menjadi aspek penting dalam pendidikan karakter semacam ini.

Pendidikan karakter yang dilakukan di Prodi Pendidikan IPS FIS UNY juga sejalan dengan visi misi yang dimiliki UNY yaitu membentuk insan/manusia yang CeMaNi (Cendekia, Mandiri, Bernurani). Nilai-nilai karakter seperti inilah yang diharapkan akan menjiwai setiap pelaksanaan kegiatan pendidikan yang berlangsung di lingkungan UNY, termasuk di lingkungan Prodi Pendidikan IPS FIS UNY.

Proses pengembangan karakter (character building) yang sedang digalakkan FIS UNY melalui mata kuliah pendidikan karakter berupaya untuk membentuk warga negara yang baik. Mata kuliah pendidikan karakter di Prodi Pendidikan IPS diberikan pada semester 5.

Berkaitan dengan jalannya pendidikan karakter perlu diteliti bagaimana persep- si dan sikap mahasiswa Prodi Pendidikan IPS, FIS, UNY. Miftah Thoha (1996: 81) menyatakan "Persepsi merupakan suatu proses kognitif yang dialami oleh setiap manusia dalam memahami lingkungannya, baik melalui penglihatan, pendengaran, penghayatan, perasaan dan penciuman".Sedangkan menurut Sugihartono, dkk (2007: 8) persepsi merupakan proses menterjemahkan atau menginterpretasi stimulus yang masuk dalam alat indera. Persepsi terdiri dari beberapa prinsip dasar yaitu:

1. Persepsi itu relatif bukannya absolut

2. Persepsi itu selektif

3. Persepsi itu mempunyai tatanan

4. Persepsi dipengaruhi oleh harapan dan kesiapan (penerima dan ransangan)

5. Persepsi seseorang atau kelompok dapat jauh berbeda dengan persepsi orang atau kelompok lain sekalipun situasinya sama. Dengan demikian dimungkinkan terjadi persepsi yang berbeda-beda tentang suatu objek yang tergantung pada tingkat pemahaman dan interpretasi masing-masing individu terhadap objek tersebut.Menurut Stagner \& Solley (Muhammad Ali, 2004: 194) tahaptahap terjadinya persepsi pada individu antara lain:

1. Adanya stimulus yang ditangkap melalui panca indera.

2. Adanya kesadaran individu terhadap stimulus.

3. Individu menginterpretasikan stimulus tersebut.

4. Individu mewujudkannya dalam tindakan.

Proses mempersepsi melalui beberapa tahapan di atas. Selain tahapan di atas, terjadinya persepsi membutuhkan beberapa syarat seperti yang dinyatakan oleh Bimo Walgito (1997: 54):

1. Ada objek yang harus dipersepsi

2. Ada alat indera atau reseptor (alat untuk menerima stimulus)

3. Ada perhatian yang merupakan langkah pertama sebagai suatu persiapan dalam mengadakan persepsi.

Sedangkan sikap (attitude) adalah gejala internal yang berdimensi afektif berupa kecenderungan untuk mereaksi atau merespon 
(response tendency) dengan cara yang relatif tetap terhadap suatu objek orang, barang baik secara positif maupun negatif (Muhibbin Syah, 2006: 149). Sikap yang ditunjukkan oleh siswa dalam kesehariannya merupakan indikator penting dari proses pendidikan. Baik perilaku yang positif atau negatif yang pada saat tertentu muncul (Dasim Budimansyah, 2002: 120). Dari sikap itulah kemudian dijadikan sebagai bahan refleksi bagi guru untuk menilai bagaimana proses pendidikan yang selama ini berlangsung.

Sikap mengandung tiga komponen yaitu komponen kognitif, afektif, dan komponen tingkah laku. Sikap selalu berkenaan dengan perasaan positif atau negatif (Slameto, 2003: 188). Komponen kognitif merupakan representasi apa yang dipercayai oleh individu pemilik sikap, komponen afektif merupakan perasaan yang menyangkut aspek emosional, dan komponen konatif merupakan aspek kecenderungan berperilaku tertentu sesuai dengan sikap yang dimiliki oleh seseorang. Ketiga komponen tersebut saling berkaitan satu dengan yang lain. Sikap adalah peniaian seseorang terhadap suatu objek tertentu. Penilaian seseorang tersebut dapat positif atau mendukung dan dapat juga negatif atau tidak mendukung, baik itu yang tersusun atas komponen koqnitif, afektif, dan konatif.

Menurut Abu Ahmadi (2002: 171) sikap seseorang memiliki ciri-ciri sebagai berikut:

1. Sikap seseorang tidak dibawa sejak lahir, tetapi harus dipelajari selama perkembangan hidupnya, karena itulah sikap selalu berubah-ubah dan dapat dipelajari. Atau sebaliknya, sikap itu dapat dipelajari apabila ada syarat tertenti yang mempermudah berubahnya sikap pada orang itu.

2. Sikap tidak semata-mata berdiri sen-diri, tetapi senantiasa mengandung relasi tertentu terhadap suatu objek. Dengan kata lain, sikap terbentuk, dipelajari, dan berubah senantiasa berkaitan dengan suatu objek tertentu.

3. Sikap dapat berkaitan dengan satu objek saja tetapi juga berkaitan dengan sedertan objek yang serupa

4. Sikap pada umumnya mempunyai segisegi motivasi dan emosi.

Untuk mengetahui bagaimana persepsi serta sikap mahasiswa Pendidikan IPS terhadap pelaksanaan pendidikan karakter pada Prodi Pendidikan IPS akan dilakukan studi pada mahasiswa angkatan 2008 dan 2009 yang telah mengikuti mata kuliah tersebut.

Berdasarkan hal di atas dapat dirumuskan permasalahan sebagai berikut:

1. Bagaimana persepsi mahasiswa pendidikan IPS terhadap pelaksanaan pendidikan karakter di Prodi Pendidikan IPS FIS UNY?

2. Bagaimana sikap mahasiswa pendidikan IPS terhadap pelaksanaan pendidikan karakter di Prodi Pendidikan IPS FIS UNY?

\section{METODE}

Sesuai dengan permasalahan yang diajukan, dilihat dari sifat dan tujuannya penelitian ini termasuk penelitian deskriptif eksploratif, karena hanya bertujuan menggambarkan keadaan atau fenomena yang terjadi di lapangan. Metode yang digunakan dalam penelitian ini adalah metode kuantitatif karena data yang terkumpul berwujud angka-angka dan diolah denggan menggunakan analisis statistik dengan bantuan program SPSS 17 for windows.Penelitian ini dilakukan di Prodi Pendidikan IPS, FIS, UNY pada bulan Agustus sampai dengan bulan September 2012.

Penelitian ini menggunakan dua variabel yaitu persepsi dan sikap. Persepsi dan sikap yang diteliti adalah persepsi dan sikap mahasiswa Prodi Pendidikan IPS, FIS, UNY terhadap pelaksanaan pendidikan karakter. Populasi dalam penelitian ini adalah seluruh mahasiswa Prodi Pendidikan IPS FIS, UNY yang telah menempuh mata kuliah Pendidikan Karakter yaitu angkatan 2008 dan 2009. Berdasarkan data yang diperoleh, jumlah mahasiswa angkatan 2008 yang masih terdaftar sebagai mahasiswa sampai dengan Agustus 2012 sebanyak 38 mahasiswa dan jumlah mahasiswa angkatan 2009 sebanyak 104 mahasiswa, sehingga total populasi sebanyak 142 mahasiswa. Penelitian ini mengambil sampel sebanyak $50 \%$ dari total populasi yaitu sebanyak 71 mahasiswa yang diambil dengan teknik proportional random sampling, sehingga diperoleh jumlah sampel dari angkatan 2008 sebanyak 19 mahasiswa 
dan sampel dari angkatan 2009 sebanyak 52 mahasiswa.

Pengumpulan data penelitian dilakukan dengan angket yang berisi seperangkat pertanyaan atau pernyataan yang diisi secara langsung oleh mahasiswa Prodi Pendidikan IPS, FIS, UNY yang menjadi responden. Instrumen yang digunakan dalam penelitian ini berupa angket untuk mendapatkan data mengenai persepsi dan sikap mahasiswa dengan mengunakan skala Likert empat alternatif jawaban: Sangat Setuju (SS), Setuju (S), Tidak Setuju (TS) dan Sangat Tidak Setuju (STS).

Analisis data meliputi pengolahan dan interpretasi hasil pengolahan data yang diperoleh atas dasar setiap variabel. Analisis yang digunakan adalah analisis statistik yang meliputi mean, median, modus, dan standar deviasi. Dari nilai data tersebut menurut Sutrisno Hadi (1991: 353) kecenderungan masing-masing variabel dapat dikategorikan sebagai berikut:

1. $>(M+1 S D i)=$ tinggi $/$ baik

2. $(M-1$ SDi) $s / d(M A+1 S D i)$

= sedang/cukup baik

3. $(\mathrm{M}-1 \mathrm{SDi})=$ rendah/tidak baik
Sesuai dengan tujuan penelitian teknik analisis data yang digunakan dalam penelitian ini adalah teknik analisis statistik deskriptif dengan persentase untuk menggambarkan keadaan dari subjek. Langkah-langkah dalam analisis tersebut adalah melalui editing, koding, tabulasi data, dan analisis data.

\section{HASIL DAN PEMBAHASAN}

Data penelitian diambil padabulan Agustus sampai dengan bulan September tahun 2012.

1. Persepsi mahasiswa terhadap pelaksanaan pendidikan karakter

Penelitian ini berupaya mengetahui persepsi mahasiswa Prodi Pendidikan IPS terhadap pelaksanaan pendidikan karakter. Dalam penelitian ini akan disajikan hasil analisis deskriptif variabel persepsi. Identifikasi kecenderungan tinggi rendahnya skor persepsi mahasiswa terhadap pelaksanaan pendidikan karakter ditetapkan berdasar kriteria ideal. Kecenderungan persepsi mahasiswa terhadap pelaksanaan pendidikan karakter dapat dilihat pada gambar berikut ini:

Gambar 1.

\section{Persepsi mahasiswa terhadap pelaksanaan pendidikan karakter}

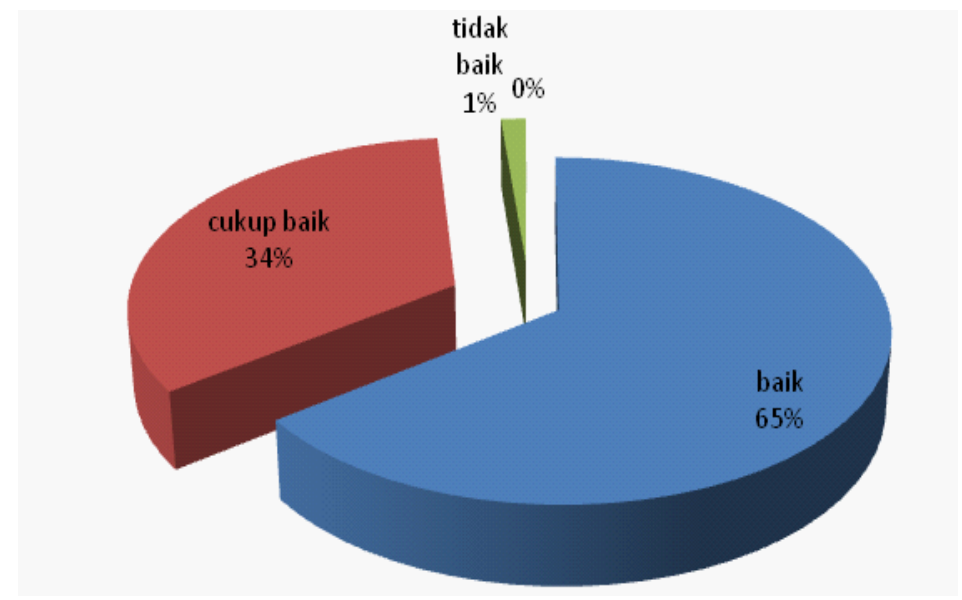

Gambar di atas menunjukkan bahwa persepsi mahasiswa terhadap pelaksanaan pendidikan karakter didominasi oleh mahasiswa yang memiliki persepsi dalam kategori baik, yakni sebanyak 64,79\%. Sementara itu yang termasuk dalam kategori cukup baik seban- 
yak 33,80\% dan yang termasuk dalam kategori tidak baik persentasenya paling kecil yaitu $1,41 \%$. Hal ini menunjukkan bahwa persepsi mahasiswa terhadap pelaksanaan pendidikan karakter yang tergolong baik jumlahnya paling banyak, atau dapat dikatakan bahwa persepsi mahasiswa terhadap pelaksanaan pendidikan karakter sudah tergolong baik, karena didominasi mahasiswa yang memiliki persepsi baik mencapai 64,79.

Apabila melihat kecenderungan di atas, dapat dikatakan bahwa persepsi mahasiswa terhadap pelaksanaan pendidikan karakter tergolong baik. Hal ini menunjukkan bahwa pelaksanaan pendidikan karakter di Prodi Pendidikan IPS, FIS, UNY telah berjalan dengan baik yang ditunjukkan dengan persepsi mahasiswa yang didominasi oleh persepsi baik. Dengan pelaksanaan pendidikan karakter pada Prodi Pendidikan IPS yang sudah dipersepsi baik oleh mahasiswa seharusnya diikuti dengan meningkatnya karakter mahasiswa Prodi Pendidikan IPS. Mahasiswa Prodi Pendidikan IPS menunjukkan ketaatan terhadap aturan dan tata tertib di lingkungan Prodi, seperti ketaatan terhadap tata cara berpakaian atau etika penampilan mahasiswa, ketaatan mengikuti kegiatan perkuliahan, keaktifan mengikuti berbagai perlombaan dan program kreativitas mahasiswa. Berdasarkan hal tersebut, Prodi Pendidikan IPS diharapkan dapat menghasilkan lulusan yang berkualitas tidak hanya secara intelektual tetapi secara moral yang ditunjukkan dengan karakter positif yang dimiliki oleh lulusan Prodi Pedidikan IPS.

Persepsi mahasiswa yang baik terhadap pelaksanaan pendidikan karakter ini harus didukung oleh seluruh jajaran Prodi maupun Fakultas agar pelaksanaan pendidikan karakter dari waktu ke waktu semakin meningkat kualitasnya. Dukungan tersebut dapat berupa teladan dari para Staff pengajar serta pimpinan yang dapat memotivasi mahasiswa agar semakin meningkatkan karakternya ke arah yang lebih positif.

Berdasar perhitungan rata-rata skor dari masing-masing indikator variabel persepsi terhadap pelaksanaan pendidikan karakter di Program Studi pendidikan IPS yang me- miliki skor terendah adalah indikator pengalaman dan praktik pendidikan karakter, skor tertinggi pada indikator pemahaman tentang pendidikan karakter. Hal ini mengindikasikan bahwa pemahaman mahasiswa terhadap pelaksanaan pendidikan karakter sudah baik akan tetapi implementasi pada kehidupan sehari-hari masih belum secara optimal. Padahal pendidikan karakter diprioritaskan untuk mengubah aspek tingkah laku mahasiswa yang notabene merupakan pengalaman dan praktik mahasiswa atas apa yang diperoleh dari mata kuliah pendidikan karakter, bukan hanya sekedar tahu dan paham tapi tidak melakukan dalam kehidupan sehari-hari. Dapat disimpulkan bahwa mahasiswa Program Studi Pendidikan IPS, FIS, UNY memiliki persepsi yang baik pada pemahaman pendidikan karakter namun persepsi terhadap pengalaman dan praktik pendidikan karakter. Pada dasarnya memang proses mendidik karakter hingga mahasiswa mampu mengubah karakter yang tidak baik menjadi baik memerlukan waktu yang relatif lama, dan hal inilah yang perlu menjadi evaluasi dan diperlukan tindak lanjut bagi Program Studi Pendidikan IPS, FIS, UNY dalam menentukan kebijakan pelaksanaan pendidikan karakter.

2. Sikap mahasiswa terhadap pelaksanaan pendidikan karakter

Identifikasi kecenderungan tinggi rendahnya skor sikap mahasiswa terhadap pelaksanaan pendidikan karakter ditetapkan berdasar kriteria ideal. Kecenderungan sikap mahasiswa terhadap pelaksanaan pendidikan karakter dapat dilihat pada gambar berikut ini:

Gambar di atas menunjukkan bahwa sikap mahasiswa terhadap pelaksanaan pendidikan karakter didominasi oleh mahasiswa yang memiliki sikap dalam kategori cukup baik, yakni sebanyak 67,60\%. Sementara itu yang termasuk dalam kategori baik sebanyak $22,54 \%$ dan yang termasuk dalam kategori tidak baik persentasenya paling kecil yaitu 9,86\%. Hal ini menunjukkan bahwa sikap mahasiswa terhadap pelaksanaan pendidikan karakter yang tergolong cukup baik jumlahnya paling banyak, atau dapat dikatakan 
bahwa sikap mahasiswa terhadap pelaksanaan pendidikan karakter tergolong cukup baik, karena didominasi mahasiswa yang memiliki sikap cukup baik mencapai 67,60\%.

Gambar 2.

Sikap terhadap Pelaksanaan Pendidikan Karakter

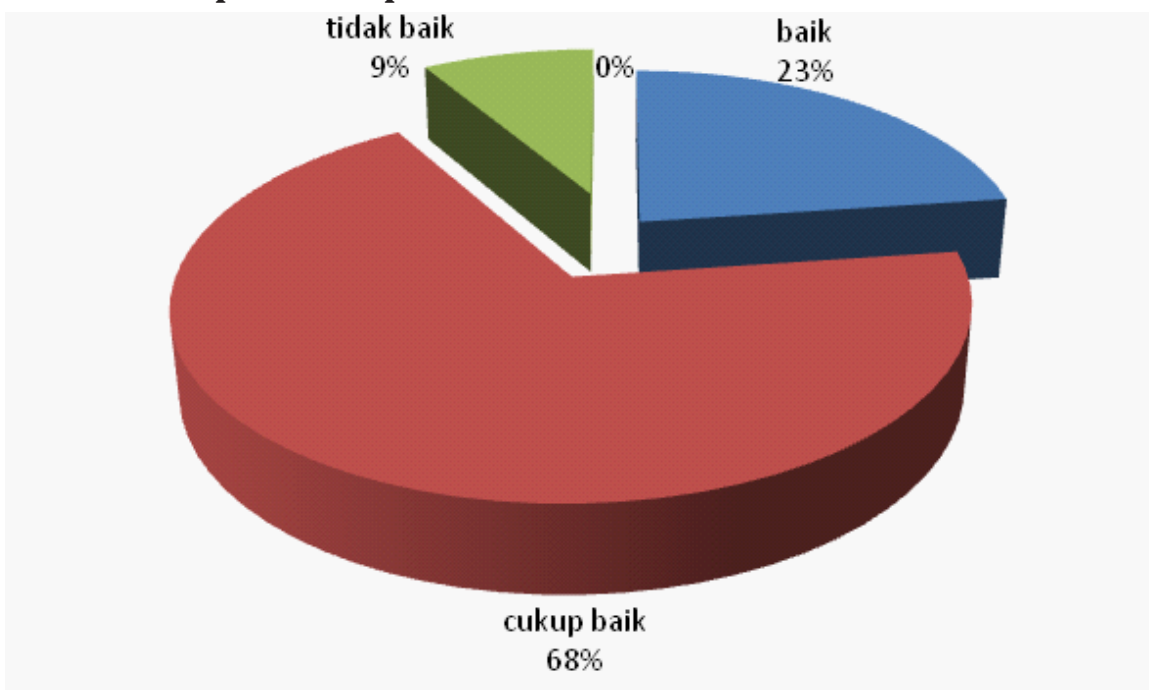

Pelaksanaan pendidikan karakter di Prodi Pendidikan IPS, FIS, UNY telah disikapi dengan cukup baik yang ditunjukkan dengan sikap mahasiswa yang didominasi oleh sikap dalam kategori cukup baik. Dengan pelaksanaan pendidikan karakter pada Prodi Pendidikan IPS yang sudah disikapi dengan cukup baik oleh mahasiswa diharapkan dapat disikapi dengan lebih baik lagi agar proses pembentukan dan penanaman karakter yang menjadi salah satu tujuan Prodi Pendidikan IPS dapat terlaksana dengan hasil yang memuasakan. Proses penanaman dan pembentukan karakter merupakan salah satu wujud pendidikan karakter bangsa. Dengan menghasikan lulusan Prodi Pendidikan IPS yang merupakan calon guru IPS SMP dengan karakter baik, diharapkan dapat menjadi salah satu teladan bagi siswa yang diajarnya kelak, sehingga dengan menjadi teladan dapat membawa perubahan pada karakter bangsa Indonesia.

Sikap mahasiswa terhadap pelaksanaan pendidikan karakter yang belum optimal dapat disebabkan karena Pendidikan karakter merupakan suatu proses yang tidak mudah dan membutuhkan waktu yang relatif lama. Mahasiswa harus melakukan serangkaian proses yang tidak mudah dalam rangka mewujudkan tujuan pendidikan karakter di Prodi Pendidikan IPS seperti menyesuaikan cara berpakaian, etika berkomunikasi, etika mengikuti perkuliahan dan lain sebagainya. Sikap mahasiswa terhadap pelaksanaan pendidikan karakter harus senantiasa ditingkatkan karena pada dasarnya pelaksanaan pendidikan karakter bermanfaat bagi mahasiswa sendiri dan juga bagi Prodi Pendidikan IPS yaitu suksesnya pendidikan karakter.

Mahasiswa yang memiliki sikap baik terhadap pelaksanaan pendidikan karakter di Prodi Pendidikan IPS, FIS, UNY telah mampu memahami tujuan pendidikan krakter dengan baik sehingga mampu menyikapinya dengan baik pula. Sikap yang baik terhadap pelaksanaan pendidikan karakter diharapkan dapat dijiwai oleh mahasiswa Prodi Pendidikan IPS, sehingga tujuan pendidikan karakter dapat tercapai dan mampu membentuk karakter mahasiswa Prodi Pendidikan IPS yang positif.

Pendidikan karakter yang dilaksanakan di Prodi Pendidikan IPS, FIS, UNY bertujuan membentuk karakter mahasiswa yang jujur, 
religius, disiplin, kerja keras, sabar, pantang menyerah, visioner, adil, cinta tanah air, dan juga tanggung jawab. Oleh karena itu jika mahasiswa telah menyikapi pelaksanaan pendidikan karakter di Prodi Pendidikan IPS diharapkan mampu mengimplementasikan nilai-nilai karakter tersebut dalam kehidupannya sehari-hari.

Berdasar perhitungan rata-rata skor dari masing-masing indikator variabel sikap terhadap pelaksanaan pendidikan karakter di Program Studi pendidikan IPS yang memiliki skor terendah adalah indikator aspek psikomotor pendidikan karakter, skor tertinggi pada indikator aspek afektif pendidikan karakter. Hal ini mengindikasikan bahwa sikap mahasiswa terhadap pelaksanaan pendidikan karakter sudah disikapi dengan baik namun belum terimplementasi dengan baik. Hal ini juga perlu mendapat perhatian bagi mahasiswa dan juga pengelola Program Studi Pendidikan IPS agar pelaksanaan pendidikan karakter berjalan dengan lancar dan tercapai hasil yang optimal.

\section{SIMPULAN}

Berdasarkan hasil penelitian dan pembahasan yang telah diuraikan dalam bab IV maka dapat ditarik kesimpulan sebagai berikut:

1. Persepsi mahasiswa terhadap pelaksanaan pendidikan karakter di Prodi Pendidikan IPS, FIS, UNY termasuk dalam kategori baik. Hal ini ditunjukkan dalam hasil penelitian yang menyatakan bahwa $64,79 \%$ dari responden memiliki persepsi baik.

2. Sikap mahasiswa terhadap pelaksanaan pendidikan karakter di Prodi Pendidikan IPS, FIS, UNY termasuk dalam kategori cukup baik. Hal ini ditunjukkan dalam hasil penelitian yang menyatakan bahwa $67,60 \%$ dari responden memiliki sikap cukup baik.

3. Dalam rangka memberikan alternatif pemecahan terhadap pelaksanaan pendidikan karakter dapat dilakukan beberapa hal yakni Mahasiswa Prodi Pendidikan IPS yang memiliki persepsi tidak baik terhadap pelaksanaan pendidikan karakter harus dapat mengubah persepsinya menjadi lebih baik agar membantu suksesnya pendidikan karakter mahasiswa. Selain itu jajaran Prodi dan Fakultas harus mendukung proses pelaksanaan pendidikan karakter karena lulusan Prodi Pendidikan IPS merupakan calon guru yang dapat menjadi teladan bagi siswanya, yang pada akhirnya akan berdampak pada perbaikan kualitas bangsa.

\section{UCAPAN TERIMA KASIH}

Kami ucapkan terima kasih kepada semua pihak yang telah membantu proses penelitian ini. Semoga hasil penelitian ini bermanfaat. Kami juga mengucapkan terima kasih kepada redaksi jurnal yang berkenan memuat artikel hasil penelitian ini sehingga dapat dibaca tidak hanya di lingkungan UNY namun juga civitas akademik lainnya.

\section{DAFTAR PUSTAKA}

Abu Ahmadi. 2002. Psikologi Belajar. Jakarta: PT. Rineka Cipta.

Darmiyati Zuchdi. 2009. Pendidikan karakter. Yogyakarta: UNY Press.

Depdiknas. 2003.Undang-Undang No. 20 Tahun 2003 tentang Sistem Pendidikan Nasional. Bandung: Fokusmedia.

Febristina Nuraini. 2012. Stimulasi motivasi belajar sebagai upaya menumbuhkan karakter pada anak usia dini.Prosiding. Yogyakarta: Fakultas Ilmu Sosial Universitas Negeri Yogyakarta.

Miftah Thoha. 1996.Perilaku organisasi, Konsep dasar dan aplikasinya. Jakarta: PT Raja Grafindo Persada.

Muhammad Ali, dkk. 2004.Psikologi Remaja Perkembangan Peserta Didik. Jakarta: Bumi Akasara.

MuhibbinSyah. 2010.Psikologi Pendidikan dengan Pendekatan Baru. Bandung: Remaja Rosdakarya.

Slameto. 2010.Belajar dan Faktor- faktor yang Mempengaruhinya. Jakarta: Rineka Cipta.

Sugihartono, dkk. 2007.Psikologi Pendidikan. Yogyakarta: UNY Press.

Suyanto \& Djihad Hisyam. 2000. Pendidikan di Indonesia memasuki millenium III. Yogyakarta: Adicita. 